\title{
Checklist and key of genera and species of the Lamiaceae of the Brazilian Amazon
}

\author{
Lista e chaves para gêneros e espécies de Lamiaceae da Amazônia brasileira
}

\author{
Raymond Mervyn Harley ${ }^{1,2}$
}

\begin{abstract}
A checklist and keys are provided for Lamiaceae native to Brazilian Amazonia (eight genera and 42 species), excluding the genera Vitex, Volkameria, Aegiphila and Amasonia, which have recently been transferred from the Verbenaceae, and for which the author did not have data. An herbarium voucher is listed for each state in which the species has been found. Notes on many cultivated taxa are included, and also a key to all species of Ocimum known from Brazil.
\end{abstract}

Key words: checklist, taxonomy, keys for genera.

\section{Resumo}

É apresentada uma lista e chaves de identificação para os gêneros nativos de Lamiaceae da Amazônia (oito gêneros e 42 especies), sendo excluídos desse trabalho os gêneros nativos Vitex, Volkameria, Aegiphila e Amasonia, que foram recentemente transferidos de Verbenaceae, e o autor não tem dados sobre os mesmos. É apresentado um voucher de herbário para cada estado no qual a espécie ocorre. Foram incluídas notas sobre os taxa cultivados e também uma chave para todas as espécies de Ocimum encontradas no Brazil.

Palavras-chave: lista de espécies, taxonomia, chave para gêneros.

\section{Introduction}

The family Lamiaceae (Labiatae) is the largest of the order Lamiales, a worldwide order including between 20 and 30 families, depending on family demarcation. Recent studies on morphology, chemistry and molecular phylogeny, have caused major changes in the family classification, resulting in the addition of a large number of genera, which had traditionally been placed in Verbenaceae (Harley et al. 2004). As a result, the family currently contains about 240 genera and 7200 species, occurring in tropical to temperate areas worldwide, except Antarctica. Of these, there are currently 32 genera and about 496 species (Harley et al. 2010), native to or naturalized in Brazil, though with many new discoveries this number is continually changing. There are seven subfamilies currently recognized, of which five occur in South America. These are
Viticoideae Briq.: Cornutia L. (1 spp.), Vitex L. (32 spp.), with Tectona L. f. and Gmelina L. which are widely cultivated); Ajugoideae Kostel: Amasonia L. f. (6 spp.), Monochilus Fisch. \& C.A. Mey. (2 spp.), Aegiphila Jacq. (c. 30 spp.), Teucrium L. (2 spp.) and Volkameria L. with 4 spp., formerly included in Clerodendrum L. (Yuan et al., 2010); Scutellarioideae (Dumort.) Caruel: Scutellaria L.(9 spp.); Lamioideae Harley: (Stachys L. (1 native and 1 introduced sp.) and with introduced genera, such as Leonotis (Pers.) R. Br., Leonurus L., Leucas Burm. ex R. Br., Lamium L., Marrubium L.) and lastly, subfamily Nepetoideae (Dumort.) Luerss.

The subfamily Nepetoideae contains about $50 \%$ of the Lamiaceae, and currently includes nineteen genera native to Brazil. Two tribes of Nepetoideae occur: tribe Mentheae, a largely temperate group, in which the stamens are

\footnotetext{
${ }^{1}$ Royal Botanic Gardens, Kew, Richmond, Surrey TW9 3AB, England, UK.

${ }^{2}$ Universidade Estadual de Feira de Santana, Programa de Pós-Graduação em Botânica, Av. Transnordestina s.n., 44036-900, Feira de Santana, Bahia, Brazil. rharley05@aol.com.
} 
ascending or spreading in the corolla: Salvia L. (62 spp.), Lepechina Willd. (2 spp.), Cunila D. Royen ex L. (11 spp.), Eriothymus (Benth.) Schmidt (1 spp., possibly extinct), Glechon Spreng. (7 spp.), Hedeoma Pers. (3 spp.), Hesperozygis Epling (7 spp.), Hoehnea Epling (4 spp.), Rhabdocaulon (Benth.) Epling (7 spp.) and Clinopodium L. (1 spp.), and tribe Ocimeae, a tropical group, characterized by the stamens declinate in the corolla: Ocimum L. (6 spp.), Eriope Bonpl. ex Benth. (c. 31 species), Eriopidion Harley (1 species), Hypenia (Mart. ex Benth.) Harley (c. 24 spp.), Hyptidendron Harley (19 spp.), Hyptis Jacq. (c. 210 spp.), Marsypianthes Mart. ex Benth. (5 spp.), Peltodon Pohl (c. 5 spp.), Rhaphiodon Schauer (1 species). All but the first of these genera belong to subtribe Hyptidinae, which is almost exclusively restricted to the Neotropics, apart from a few pan-tropical weeds.

We can now calculate (Harley et al. 2010) that of the 484 Lamiaceae species native to Brazil, there are 4 endemic genera and 334 or $69 \%$ of endemic species. Hyptis, the genus with the largest number of species in Brazil, has 69.5\% endemism, although, as rarer species are discovered, these figures are likely to increase.

The Lamiaceae, is of considerable economic importance, containing several timber trees, such as Tectona, many species of horticultural value, many used as culinary herbs, or in perfumery and many are used medicinally. Also the trade in honey, which is an important part of the rural economy, is reliant on the many nectar-producing species of Lamiaceae, which produce a honey of high quality.

In particular, many species of Nepetoideae are noted for their aromatic oils, and many have commercial or cultural importance, such as: Salvia officinalis L., Rosmarinus officinalis L., Mentha L. spp., Thymus vulgaris L., Origanum L. spp., Satureja hortensis L., Monarda L. spp., Melissa officinalis L., Lavandula L. spp., Aeollanthus suaveolens Mart. ex Spreng., Ocimum spp., Plectranthus L'Hér. spp. All but the last four of the above genera belong to tribe Mentheae, these last, to the tribe Ocimeae.

Species cultivated in Brazilian Amazonia have not been well-documented. As a result the list here is only provisional. Congea tomentosa Roxb., sometimes placed in a separate family Symphoremataceae, is a robust climber, grown as an ornamental, with small white flowers, surrounded by $3-4$ elongate, spreading pink bracts; Clerodendrum chinense (Osb.) Mabb. (syn.:
C. fragrans (Vent.) R. Br. and C. philippinum Schauer) is a robust herb or subshrub with large, broadly ovate leaves and terminal, compact cymes of, strongly perfumed, white or pale pink flowers; Rotheca myricoides (Hochst.) Steane \& Mabb. (formerly included in the genus Clerodendrum) is a bush with showy bluish lilac, zygomorphic flowers, with the anterior petal larger than the other four. Gmelina arborea Roxb. is a tree with ovate, subcordate leaves, and yellow and orange flowers, which is often planted for shading young plantation trees, another species, Gmelina philippensis Cham. (syn. G. hystrix Kurz), is an ornamental with elliptic leaves, yellow flowers and broad often purplish bracts; Holmskioldia sanguinea Retz. is a scandent, ornamental shrub with showy red, or rarely pale yellow, saucer-shaped calyx and slender, tubular red or yellow corolla; Tectona grandis L. f., (Engl.: teak) is a large tree from Asia, which can reach $50 \mathrm{~m}$ at maturity, with very large elliptic leaves and massive inflorescences of small white flowers, and drupaceous fruits surrounded by a 2.5 $\mathrm{cm}$ long, persistent, inflated calyx. Occasionally planted it is noted for its valuable timber (Harley et al. 2004); three commonly cultivated species of Ocimum are aromatic culinary and medicinal herbs, and a key is provided of all species occurring in Brazil, in the main text; Plectranthus amboinicus (Lour.) Spreng. is a fleshy, aromatic, culinary herb with elongate thyrses of pinkish flowers, $P$. barbatus Andr. is an ornamental herb or shrub with purple corolla, fruiting calyx hairy at throat; Aeollanthus suaveolens Spreng. is a strongly aromatic, fleshy annual herb, with tubular white, sessile flowers borne in a branched terminal spike and a circumscissile fruiting calyx, introduced from Africa and used in religious rites; Mentha spicata L. and its hybrids are aromatic, rhizomatous herbs, cultivated as potherbs, these have small white or lilac flowers, almost actinomorphic, in terminal spike-like or verticillate inflorescences, the stamens are typically exserted, although in hybrids and in female flowers of gynodioecious species these are usually reduced and infertile. Many other genera are frequent in cultivation. Perhaps one of the showiest, not mentioned so far is Salvia, with an increasing number of species to be found in gardens for their ornamental value. The red-flowered $S$. splendens Sello ex R. \& S., a native of S Brazil, is perhaps the most common. With the horticultural trade expanding rapidly, the number of new species 
of Lamiaceae likely to occur in cultivation in Amazonia, is bound to increase.

The most recent published accounts, which treat Brazilian species of Lamiaceae and purport to account for all known species, are almost all outof-date and overdue for revision. The most widely used are those of Epling (1935, 1936a,b,1937, 1942, 1949): respectively a review of South American Labiatae, a revision of American Scutellaria and a revision of the genus Hyptis, and Harley (1976): a revision of Eriope. The only exception is the account of Ocimum (Paton et al. 1999), which is unfortunately not easily obtainable, and which I have relied on for the key to species included below.

The author is at present engaged in a revision of the Hyptidinae, which is the main group of Lamiaceae found in Brazil, including generic reorganization (Harley \& Pastore, in press), but many other groups would benefit from modern revisionary treatment.

\section{Materials and Methods}

Following a visit in 2007 to the Museo Goeldi in Belém, Pará, I began to assemble records of Lamiaceae, especially subtribe Hyptidinae, which represents the major part of the family, for Amazonia. A decision was made to restrict the study area to the states of Amapá, Amazonas, Acre, Pará, Rondônia and Roraima, omitting Mato Grosso and Maranhão (Fig. 1), on the grounds that, while parts of these fall within Amazonia, a large area of each of these states cannot be considered Amazonian. Where, however, records of Amazonian species occur from these last two states, these have been listed. This has enabled the omission of a large number of Lamiaceae, typical of the cerrados of southern Brazil, which have never been recorded from Amazonia. Undoubtedly there will still be many gaps in the record, but it is hoped that the present paper will stimulate others to assist in filling them, as well as aid the identification of Lamiaceae from the area.

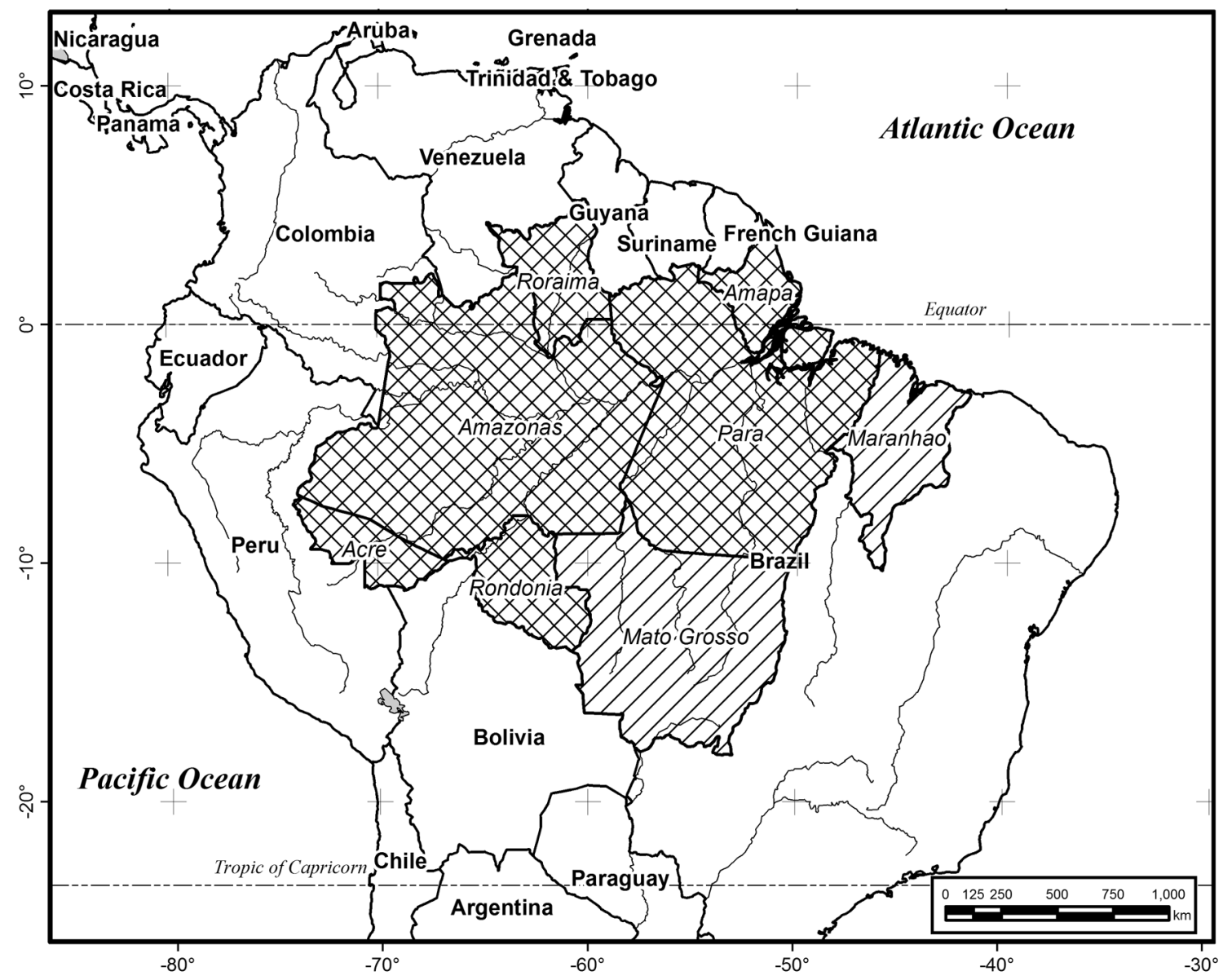

Figure 1 - Map of Northern Brazil indicating the states covered in this work. 
In the following checklist, a single representative specimen of each native taxon from each state has been cited, and dichotomous keys have been provided, to enable fresh or herbarium material to be easily determined. Every specimen cited, with the sole exception of the specimen of Hyptidendron canum (Pohl ex Benth.) Harley from Amazonas, has been seen and verified by the author. Synonymy has only been included if the synonym is one still occasionally to be found in use. The list includes most members of the family to be encountered, however certain genera have been omitted, due to insufficient knowledge. Those native to Amazonia, but not included in this list, are genera such as Vitex, Aegiphila, Volkameria (Clerodendrum pro parte), and Amasonia, which have recently been removed from Verbenaceae and placed in Lamiaceae (Harley et al. 2004). I have not been keeping records of these genera and my knowledge of their species is incomplete. They are included in the generic key, together with naturalized genera, however. Cultivated species are not included, although a number of those likely to occur, are mentioned below.

\section{Results and Discussion}

\section{Description of Lamiaceae}

Trees, shrubs, subshrubs or perennial or annual herbs, rarely climbers, aromatic or not. Roots rarely tuberous. Stems often quadrangular, erect to prostrate, sometimes forming stolons or rhizomes. Indumentum usually present, of glandular and nonglandular trichomes, often hair-like, rarely scale-like, usually multicellular-uniseriate, simple, branched, dendroid or stellate, sometimes gland-tipped, largeheaded subsessile glands rarely absent. Leaves opposite, often decussate, sometimes whorled, very rarely alternate, simple, entire, toothed or lobed, sometimes compound and then digitate or pinnate, petiolate or sessile, rarely forming a basal rosette, exstipulate. Inflorescence often bracteate, bracts sometimes conspicuous, persistent or deciduous, rarely (Lavandula and Scutellaria) spirally arranged, composed of cymes, bracteolate or not, and often arranged in a terminal, lax or congested indeterminate thyrse which may be paniculate, raceme-like with cymes often 1-flowered, or spike-like, or rarely congested into a capitulum, with or without a distinct involucre of bracteoles. Flowers hypogynous, usually bisexual, or less often unisexual due to gynodioecy or gynomonoecy, very rarely due to dioecy. Perianth biseriate, sepals usually $4-5$, connate, actinomorphic to zygomorphic, sometimes 2-lipped, lobes often 5 , equal or unequal, rarely obsolete, some lobes often fused, or lips entire, calyx-tube (5-)10-15-nerved, straight or curved, throat hairy or glabrous, calyx often accrescent, rarely inflated or fleshy in fruit. Petals (4-)5 connate, usually slightly to strongly zygomorphic, often 2-lipped, rarely 1-lipped, lobes (2-)4-5, equal or unequal, porrect to patent, one or other lip often concave to galeate, corolla-tube short to elongate, rarely spurred, often with annulus of hairs or appendaged within, rarely corolla resupinate. Stamens epipetalous, attached within corolla-tube, usually 4 , or 2 by abortion and then staminodes often present, rarely stamens $5(-8)$, when 4 often didynamous (rarely a fifth, posterior vestigial staminode present), free or rarely monodelphic, filaments short or often elongate, usually exserted from corolla-tube and sometimes long-exserted from corolla; parallel, divergent or ascending and sometimes included within or lying under the posterior corolla-lip, or declinate and then sometimes included within the anterior corolla-lip, anthers usually dithecous, tetrasporangiate or monothecous by abortion, thecae parallel or divergent, occasionally widely separated by an elongate connective, or apically confluent or synthecous, opening by longitudinal slits or rarely by pores. Disc at base of ovary often present, usually fleshy, entire or irregularly or often 4-lobed, anterior lobe sometimes longer than others, nectariferous. Gynoecium 2-carpellate, often 4-locular by intrusion of carpel wall forming "false septum", or rarely imperfectly 2-locular and free towards apex, ovary usually 4-ovuled, 2-locular ovaries generally with loculi 2-ovuled and 4-locular ovaries with 1 ovule per loculus, ovary entire or lobed, with terminal style, or more often deeply 4-lobed, the loculi often separated and with style gynobasic, style usually with 2 equal or unequal stigma-lobes, rarely entire with 1 stigma-lobe vestigial, or stigma capitate or very rarely 4-lobed. Ovules anatropous to hemianatropous, usually basal or sub-basal, erect, rarely orthotropous, apical, pendulous, borne laterally or submarginally on the placenta, unitegmic, tenuinucellate. Fruit drupaceous, often with pyrenes, or more often dry, indehiscent, or separating into two 2-seeded or frequently, four 1-seeded mericarps, sometimes fewer by abortion. Mericarps (nutlets) with rugulose, sculptured, tuberculate, hairy or rarely winged pericarp, mucilage cells often present. Seeds albuminous or exalbuminous, epigeal. Embryo straight or bent, investing or spatulate. The family contains about 235 genera and about 7200 species, almost cosmopolitan, but absent from the coldest regions of high latitude or altitude. 


\section{Key to native \& naturalized genera from the Amazon}

1. Ovary undivided, fruit drupaceous, usually remaining entire, style terminal.................................... 2 Ovary 4-lobed, fruit dry, divided into four nutlets, style gynobasic ............................................... 7

2. Leaves digitately compound, rarely unifoliolate. Corolla zygomorphic. Fruit a 4-seeded pyrene

...Vitex†

Leaves undivided. Corolla actinomorphic to weakly zygomorphic. Fruit of usually four 1-seeded pyrenes

3. Corolla usually 4-lobed, stamens as many as lobes ........................................... Aegiphila $\dagger$ Calyx and corolla 5-lobed 4

4. Erect subshrubs, often branched only at base, leaves often alternate, bracts showy, coloured

Branched shrubs (or lianas in some cultivated spp.) bracts not coloured

5. Flower-bud markedly asymmetrical, corolla expanding abruptly on lower side only, not resupinate; anterior corolla lobe much larger than other four Rotheca* Flower-bud symmetrical, or if asymmetrical, expanding abruptly on upper side due to resupination; corolla lobes subequal

6. Branches not tuberculate; inflorescence usually terminal; fruiting calyx accrescent, larger than fruits, brightly coloured Clerodendrum* Branches tuberculate; inflorescence often axillary; fruiting calyx rarely accrescent, small, enclosing base of fruit, not brightly coloured Volkameria $\dagger$

7. Calyx two-lipped, the lips entire, closed in fruit, with a rounded scale-like appendage (the scutellum) on the upper lip 8. Scutellaria Calyx 5- or more- lobed, without a scale-like appendage on the upper lip, though sometimes the broad upper lobe with decurrent wings ............ 8

8. Stamens held under the upper lip of the corolla. Calyx-lobes spinose. Introduced species

Stamens directed towards the lower lip of the corolla. Calyx-lobes not spinose, if \pm obsolete then with a dense tuft of white hairs in the throat

9. Calyx lobes 5, corolla pink, leaves deeply lobed ... Leonurus* Calyx lobes 8-10, corolla other colours, the uppermost longer, leaves toothed, unlobed

10. Corolla white, 4-6 mm long ............................ Leucas* Corolla orange (or yellow), c. $19 \mathrm{~mm}$ long or more

Leonotis*

11. Calyx strongly zygomorphic, the upper lobe broad and decurrent in a wing along the calyx tube

6. Ocimum

Calyx not strongly zygomorphic, upper lobe not as above. .12

12. Nutlets concave cymbiform, with an involute, fimbriate margin on inner face. Viscid herb with blue-violet flowers in small heads

.5. Marsypianthes

Nutlets ovoid or flattened but not as above. Plant without the above combination of characters ..

13. Upper stem with pruinose and often swollen, fistulose internodes 2. Hypenia Stems never swollen nor pruinose 14 
14. Inflorescence a slender raceme of bluish flowers. Calyx turbinate, with a conspicuous tuft of white hairs in throat, when in fruit

Inflorescence cymose or capitulate

15. Flowers in \pm lax cymose panicles

3. Hyptidendron

Flowers more densely clustered, often in capitula, with an involucre of bracteoles 16

16. Calyx lobes not foliaceous at apices

Calyx lobes with small foliaceous appendage at apex

7. Peltodon

Note: $\uparrow$ Native taxa not included in this work. *Taxa introduced from Old World, naturalized or in cultivation.

1. Eriope Bonpl. ex Benth.

1.1 Eriope crassipes Benth., Lab. Gen. et Sp.: 144(1833). subsp. crassipes.

Selected material: PARÁ: Trombetas, W.A. Egler 373 (MG). MATO GROSSO: "Xavantina-Cachimbo Expedition Base camp", $12^{\circ} 49^{\prime}$ 'S, 51 ${ }^{\circ} 46^{\prime}$ 'W, R.M. Harley \& R. Souza 10319 (K, UB).
Extra-Amazonian distribution: French Guiana, Colombia, Venezuela, Bolivia, Brazil: Pernambuco and Tocantins, south to Goiás, Distrito Federal, Minas Gerais to São Paulo and Paraná. A typical cerrado species, with other subspecies occurring in southern Brazil and Paraguay.

\section{Hypenia (Mart. ex Benth.) Harley}

1. Corolla bright red, with tube $13-18 \mathrm{~mm}$ long 1. H. macrosiphon Corolla pale blue to pale lilac, with tube 5-6 $\mathrm{mm}$ long 2. H. salzmannii

2.1 Hypenia macrosiphon (Briq.) Harley, Bot. J. Linn. Soc. 98: 92 (1988). Hyptis macrosiphon Briq., Bull. Herb. Boissier 4: 785 (1896).

Selected material: PARÁ: Serra do Cachimbo, $M$. Alvarenga (90546) (RB). RONDÔNIA: Vilhena, M.G. Silva \& C. Rosário 4565 (MG). MATO GROSSO: Chapada dos Guimarães, G. Hatschbach et al. 66612 (K, MBM).

Extra-Amazonian distribution: Paraguay, E. Bolivia, Brazil: Mato Grosso do Sul, Goiás.

2.2 Hypenia salzmannii (Benth.) Harley, Bot. J. Linn. Soc. 98: 91 (1988). Hyptis salzmannii Benth., Lab. Gen. et Sp.: 138 (1833).
Selected material: RORAIMA: Pacaraíma, $R$. Schomburgk $177 \mathrm{~S}$ (K).

Extra-Amazonian distribution: Brazil: Piauí, Ceará, Paraíba, Pernambuco, Alagoas, Sergipe and Minas Gerais. Venezuela: Bolivar, Monagas $\&$ Anzoategui. This species shows a remarkable disjunction between the Venezuelan Guayana and the semi-arid of NE Brazil. Schomburgk's collection, over 170 years ago, was originally described as being from "British Guiana", but was near the border between Brazil and Venezuela. It is hoped that the species will be refound in this area, to confirm its presence.

\section{Hyptidendron Harley}

1. Viscous subshrub with ovate-cordate leaves. Indumentum of simple, mostly gland-tipped hairs 3. H. glutinosum

Subshrubs, shrubs or trees. Indumentum of dendroid, non-glandular hairs .2

2. Shrubs or trees, usually $2-20 \mathrm{~m}$ tall. Some leaves $>4 \mathrm{~cm}$ long, ovate to ovate-lanceolate. Indumentum of foliar bracts, subtending flowers, conspicuous, white to pink on both surfaces. Calyx tube 6-11 mm long at maturity, corolla tube $>8 \mathrm{~mm}$ long

2'. Herb or subshrub to ca. $1 \mathrm{~m}$ tall. Leaves oblate to rotund $<2 \mathrm{~cm}$ long. Foliar bracts without indumentum as above. Calyx tube $<4.5 \mathrm{~mm}$ long at maturity, corolla tube $\pm 3.5 \mathrm{~mm}$ long

3. Calyx lobes $2-2.5 \mathrm{~mm}$ long, with tube $6-8 \mathrm{~mm}$ long at maturity 4. H. rondonicum Calyx lobes $3-3.5 \mathrm{~mm}$ long, with tube $8-11 \mathrm{~mm}$ long at maturity 1. H. arboreum 2. H. canum 
3.1 Hyptidendron arboreum (Benth.) Harley, Bot. J. Linn. Soc. 98: 93 (1988). Hyptis arborea Benth. in A.P. de Candolle, Prodr.12: 132 (1848).

Selected material: RORAIMA: Venezuela and Roraima frontier: Serra Sebang, B. Maguire \& C.K. Maguire 40340 (K, NY).

Extra Amazonian distribution: apart from its occurrence in the Guiana Highlands, bordering Brazil, Venezuela and Guyana, it occurs also in Colombia and around Lake Titicaca in Peru and in Bolivia.

3.2 Hyptidendron canum (Pohl ex Benth.) Harley, Bot. J. Linn. Soc. 98: 93 (1988). Hyptis cana Pohl ex Benth., Lab. Gen. et Sp.: 135 (1833).

Selected material: AMAZONAS: Apuã, campinarana, F.A. Carvalho \& P. Assunção 2127 (?). MATO GROSSO: Between Cuiabá and Rondonópolis, B. Maguire et al. 56374 (NY).

Extra Amazonian distribution: A characteristic cerrado tree, especially in the southern part of its range, recorded from Brazil: Bahia, Distrito Federal, Goiás, Mato Grosso do Sul, Minas Gerais, São Paulo. Bolivia: Santa Cruz.

Note: I have been unable to see actual material of this species, although photographs, taken by the collectors, clearly indicate its identity. Unfortunately I have no information as to the herbarium where the material was deposited. The species may well occur in similar habitats in Amazonas and possibly Pará. At present the specimen from Amazonas is the northernmost locality recorded for this species.
3.3 Hyptidendron glutinosum (Benth.) Harley, Bot. J. Linn. Soc. 98 : 93 (1988). Hyptis glutinosa Benth. in A.P. de Candolle, Prodr.12: 130 (1848). Selected material: RONDÔNIA: Colorado do Oeste, C.A. Cid et al. 4354 (K). MATO GROSSO: Cuiabá, M.H. Lima \& J.G.S. Maia (HUEFS). Cerrado.

Extra-Amazonian distribution: in E Bolivia.

3.4 Hyptidendron rondonicum (Harley) Harley, Bot. J. Linn. Soc. 98 : 94 (1988). Hyptis rondonica Harley, Kew Bull. 41: 141 (1986).

Selected material: RONDÔNIA: Vilhena, I.S. Miranda \& P.J.D. Silva 1459 (MG). MATO GROSSO: Nova Marilândia, E.B. Souza 1289 (HUEFS).

Extra-Amazonian distribution: None. Endemic to Amazonian Brazil.

\section{Hyptis Jacq.}

Owing to the size of the genus Hyptis, as recognized here, the section, to which each species currently belongs, has been interpolated between the genus name and the specific epithet. The genus is likely to undergo major taxonomic changes in the near future, involving the recognition of a number of new genera, due to recent molecular phylogenetic studies (Pastore et al. 2011). Many of the sections currently recognized have proved to be monophyletic, so that their recognition here should assist in placing the species, cited in this work, in context.

\section{Key to Hyptis species from Brazilian Amazon}

1. Flowers in sessile or pedunculate cymes, of cincinni or verticillasters, congested or not, sometimes forming a terminal congested or interrupted spiciform inflorescence, but never in capitula or compact cymes, surrounded by a distinct involucre of bracteoles Flowers in compact cymes or capitula, sessile or pedunculate, surrounded by a distinct involucre of bracteoles

2. Flowers in short or long-pedunculate, few flowered cymes, at least the lower ones from the axils of foliaceous bracts. Inflorescence not spiciform. Fruiting calyx with tube 5-7 mm long. Leaves aromatic .................. 3 Flowers not arranged as above, in cincinni or verticillasters and then often forming a congested or interrupted spiciform inflorescence. Fruiting calyx with tube 2-4 mm long. Leaves aromatic or not .... 4

3. Peduncles spreading, 2-4 cm long. Calyx lobes $1-2 \mathrm{~mm}$ long with acute but muticous apex. Ripe nutlets with swollen white appendage covering the basal scar 9. H. eximia Peduncles short, $<1 \mathrm{~cm}$ long, not distinctly spreading. Calyx lobes c. $2 \mathrm{~mm}$ long, apex weakly spinose 27. H. suaveolens

4. Flowers arranged in paired cincinni on a short peduncle, sometimes forming a spiciform terminal thyrse. Flowers erect, calyx with white tuft of hairs in throat, corolla $<2.5 \mathrm{~mm}$ long 23. H. pectinata

Flowers arranged in a congested or interrupted spike 5 
5. Flowers arranged in an elongate compact spike, leaves lanceolate, long-petiolate, \pm glabrous, not rugose 26. H. spicigera Flowers arranged in globose verticillasters, forming an interrupted spike, if spike not interrupted, leaves hairy, strongly rugose

6. Inflorescence borne on an elongate stem with leaves basal or near base, petiole distinct. Calyx tube strongly deflexed just below throat at maturity 7 Inflorescence axis leafy below, with lower verticils subtended by leaf-like bracts. Leaves oblonglanceolate, sessile with base of lamina narrowly attenuate. Calyx tube not deflexed below throat at maturity. (Involucral bracts present but often obscured) 10. H. hirsuta

7. Calyx at anthesis c. 3.3-3.5 mm long, with lobes $1.5-1.7 \mathrm{~mm}$ long. Calyx in fruit with tube 2.3-3.0 mm long, lobes $1.6-2.0 \mathrm{~mm}$ long, rigid . 28. H. sp. nov. Calyx at anthesis c. 6-6.5 mm long with lobes 3.2-4.6 mm long. Calyx in fruit with tube 4-5 $\mathrm{mm}$ long, lobes 3.5-4.5 $\mathrm{mm}$ long, setaceous 11. H. interrupta

8. Flowers in compact cymules, never globose or hemispherical, and arranged in often branched spiciform or raceme-like inflorescences

Flowers in globose or hemispherical capitula

9. Leaves sessile, broadly elliptic to oblong-ovate with cordate base, cymules \pm sessile, forming broad spiciform inflorescences c. 1-2 cm diam. 5. H. carpinifolia Leaves petiolate, ovate to ovate rhomboid with attenuate to truncate base, cymules shortly pedunculate, $<1 \mathrm{~cm}$ long, forming rather slender raceme-like inflorescences 19. H. mutabilis

10. Leaves pinnatifid with elongate, deeply toothed lobes 12. H. laciniata Leaves entire, toothed or shallowly lobed, but never pinnatifid 11 11. Fruiting calyx tube becoming strongly deflexed below throat ............. 12 Fruiting calyx tube straight or very slightly curved, never deflexed ... 14 12. Leaves small, grey to grey-green tomentose, $<1 \mathrm{~cm}$ wide spathulate to narrowly obovate, with rotund apex and base long-attenuate into short, indistinct petiole 17. H. microphylla Leaves green, rather thinly hairy, cauline leaves usually over $1.5(-3.5) \mathrm{cm}$ wide, ovate with usually acute apex and cordate, rounded or abruptly attenuate base, petiole $>1 \mathrm{~cm}$ 13

13. Fruiting capitula c. $8-9 \mathrm{~mm}$ diam., calyx tube densely greywhite tomentose above, on posterior side with very short patent trichomes, lobes c. $1 \mathrm{~mm}$ long 18. H. microsphaera Fruiting capitula c. $10-15 \mathrm{~mm}$ diam., calyx tube subglabrous above, or with scattered longer trichomes on posterior side, lobes c. $1-1.5(-2) \mathrm{mm}$ long 25. H. recurvata 14. Sinus between anterior calyx lobes deeper than others, sinuses very narrow 24. H. pulegioides Sinuses equal, usually wider 15

15. Leaves sessile or almost so, strongly coriaceous, rugose and glabrous with veins on abaxial surface strongly reticulate, incrassate .....20. H. nigrescens Leaves petiolate, or if sessile not as above 16

16. Leaves densely hairy beneath, with broad, sessile and sometimes cordate base. Capitula densely hairy, trichomes often obscuring the calyces 17 Leaves hairy or glabrous, petiolate or if sessile, lamina usually narrowing toward base. Capitula glabrous or hairy, but never so densely as to obscure the calyces 
17. Leaves smooth, densely appressed-hairy on both surfaces, small, $<\mathrm{c} .12 \mathrm{~mm}$ long, erect and appressed to stem

Leaves rugose, more densely hairy below, at least the cauline leaves $>2 \mathrm{~cm}$ long, spreading or ascending, but never appressed to stem

18. Leaves 3.5-7 times longer than wide, linear-oblong to ovate-oblong with often dilated base ....... 8. H. dilatata

Leaves up to 2.5 times longer than wide, broadly ovate to shortly ovate-oblong, base not dilated. (intermediate forms with previous species occasionally occur)

7. H. crenata

19. Calyx lobes subulate or acicular 21

Calyx lobes broadly or narrowly deltate, never with sharply pointed apex ......

20. Calyx lobes narrowly deltate, not spreading, fruiting capitulum $13-16 \mathrm{~mm}$ diam.

13. H. lacustris

Calyx lobes very broadly deltate, often slightly spreading, fruiting capitulum $<10-12 \mathrm{~mm}$ diam. 22. H. parkeri

21. Leaves \pm rugose, coarsely villous with long hairs, leaves broadly obovate-elliptic to oblanceolate, calyx lobes subulate, rigid, $2.5-4 \mathrm{~mm}$ long. Herbaceous stems from well-developed xylopodium 22 Leaves not rugose or if so, not coarsely villous, leaves ovate or lanceolate if calyx lobes as above, then leaves glabrous or thinly hairy. Xylopodium absent or not well-developed .23

22. Inflorescence of sessile, globose verticils in the axils of leaf-like bracts, these often reduced toward apex with inflorescence becoming an elongate, interrupted spike 10. H. hirsuta Inflorescence of long-pedunculate capitula from the axils of the upper leaves and forming a lax corymb 1. H. alutacea

23. Calyx internally with a ring of hairs in mid-tube, above nutlets ....... 24 Calyx internally glabrous or with scattered hairs not forming a ring in mid-tube

24. Fruiting calyx with tube $8-10 \mathrm{~mm}$ long and lobes $2-2.5 \mathrm{~mm}$ long, fruiting capitulum \pm globose, $2.0-2.6(-3) \mathrm{cm}$ diam. becoming dark brown 4. H. capitata Fruiting calyx with tube $<5.5 \mathrm{~mm}$ long and lobes $1-4.3 \mathrm{~mm}$ long, fruiting capitulum if more than $2.0 \mathrm{~cm}$ diam., then calyx lobes 3-4.5 $\mathrm{mm}$ long 25

25. Fruiting calyx with lobes $3-4.5 \mathrm{~mm}$ long, robust herb with erect stems and coriaceous leaves, at least some usually $7 \mathrm{~cm}$ long or more, sometimes $<15 \mathrm{~cm}$ long 6. H. conferta Fruiting calyx with lobes $<2.5 \mathrm{~mm}$ long, weak-stemmed herbs often supported by surrounding vegetation, or prostrate to ascending, leaves membranous, $<5 \mathrm{~cm}$ long, usually less ..

26. Calyx lobes c. $1 \mathrm{~mm}$ long. Leaf-base truncate or rarely weakly cordate, becoming abruptly and narrowly decurrent onto $<1 \mathrm{~cm}$ long petiole. Mature capitula greenish

16. H. lorentziana

Calyx lobes c. $2-2.5 \mathrm{~mm}$ long. Leaf-base acuminate to indistinct 1-4 $\mathrm{mm}$ long petiole, Mature capitula often turning straw coloured or reddish-brown 
27. Involucral bracteoles of capitulum \pm ovate to often broadly elliptic, calyx with finely setaceous lobes separated by truncate sinuses. Style jointed below, with persistent base overtopping ovary

2. H. atrorubens

Involucral bracteoles of capitulum linear to linear-lanceolate, calyx with lobes terminating in a long, finely subulate to setaceous apex and separated by narrower rounded sinuses. Style not jointed below, soon deciduous from the base

28. Calyx lobes usually $1.5-2.4 \mathrm{~mm}$ long, peduncles $0.3-1.5 \mathrm{~cm}$ long, abaxial surface of leaf, and often the stems, with usually sparse, spreading trichomes 3. H. brevipes Calyx lobes usually $1.5 \mathrm{~mm}$ long or less, peduncles 1-2 $\mathrm{cm}$ long, abaxial surface of leaf and stem glabrous or with appressed trichomes 14. H. lanceolata

4.1 Hyptis (Xylodontes) alutacea Pohl ex Benth., Labiat. Gen. Spec.: 112 (1833).

Selected material: PARÁ: Marajó, A.S.L. Silva \& C.S. Rosário 2102 (MG). MARANHÃO:Amarante do Maranhão, G. Eiten \& L.T. 10225 (US). MATO GROSSO: Bandeirantes, G. Hatschbach \& C. Koczicki 33043 (K, MBM).

Extra-Amazonian distribution: Brazil: Tocantins, Goiás, Minas Gerais, Mato Grosso do Sul.

4.2 Hyptis (Pusillae) atrorubens Poit., Ann. Mus. Hist. Nat. 7: 466 (1806).

Selected material: ACRE: Rio Branco, E. Ule 5225 (MG). AMAZONAS: Reserva Florestal Ducke, M.A.S. Costa et al. 215 (MG). AMAPÁ: Rio Oiapoque. W.A. Egler et al. 47225 (MG). PARÁ: Conceição do Araguaia, T. Plowman et al. 8744 (MG). RORAIMA: Ilha de Maracá, J. Pruski et al. 3448 (INPA). MARANHÃO: Alcântara, A. Araújo \& S.J.M. Gonçalves 5 (MG).

Extra-Amazonian distribution: Widely distributed from Mexico and the Caribbean, South America: south to Peru, Bolivia and throughout most of tropical Brazil south to SP. Tropical Africa.

4.3 Hyptis (Hyptis) brevipes Poit., Ann. Mus. Hist. Nat. 7: 465 (1806).

Selected material: ACRE: Santa Rosa, D.C. Daly et al. 11027 (NY). AMAZONAS: Rio Javari, P. Cavalcante 3175 (MG). PARÁ: Maicurú, J.M. Pires et al. 6543 (UB). RONDÔNIA: Jaru, C.B. Toledo et al. 162 (HUEFS). MATO GROSSO: Poconé, J.U. Santos \& C.S. Rosário 591 (MG).

Extra-Amazonian distribution: Widespread, from Mexico, $\mathrm{S}$ to Bolivia and Argentina.

4.4 Hyptis (Hyptis) capitata Jacq., Collectanea 1: 102 (1787).

Selected material: ACRE: Sena Madureira, Oliveira, A.R.S. et al. 466 (NY).

Extra-Amazonian distribution: From U.S.A. (Florida), Central America and the Caribbean \& Guyana, to Western S. America: Venezuela and Colombia, Ecuador, E. Peru. Introduced into tropical Asia, Indian Ocean and Pacific islands). This is the only confirmed record from Brazil.
4.5 Hyptis (Polydesmia) carpinifolia Benth., Labiat. Gen. Spec.: 115 (1833).

Selected material: RORAIMA: Guaporé, $R$. Scolnik \& R. Luti 742 (NY). MATO GROSSO: Nova Xavantina, H.S. Irwin et al. 17437 (K, RB, U, UB).

Extra-Amazonian distribution: Brazil: Tocantins, Piauí, S to Mato Grosso do Sul and São Paulo. Bolivia.

4.6 Hyptis (Hyptis) conferta Pohl ex Benth., Labiat. Gen. Spec.: 112 (1833).

var. angustata (Briq.) Pool \& Harley, Novon 4: 45 (1994).

Selected material: AMAZONAS: Fortaleza do Ituxí, G.T. Prance et al. 13827 (K, MG). RONDÔNIA: Alvorada d'Oeste, M.G. Silva 6311 (MG). MATO GROSSO: Nova Xavantina, D.R. Hunt 5810 (K, UB).

Extra-Amazonian distribution: Southern Mexico south through Central America to S America: Venezuela, Colombia, to Bolivia and Brazil: Piauí, Tocantins to Minas Gerais and São Paulo. Differs from var. conferta by having leaves 4 times longer than broad. Although intermediates have been found, the typical forms are often strikingly different in appearance.

var. conferta

Selected material: AMAZONAS: Humaitá, L.O.A. Teixeira et al. 1314 (K, MG).

Extra-Amazonian distribution: similar distribution to that of var. angustata, but much less common. Differs from var. angustata in having leaves up to 3.5 times longer than broad.

4.7 Hyptis (Eriosphaeria) crenata Pohl ex Benth., Labiat. Gen. Spec.: 93 (1833).

Hyptis goyazensis A.St.-Hil. ex Benth., Labiat. Gen. Spec.: 92 (1833), as "goyavensis". Type: in campis prope Laage (holotype P!). Syn. nov.

Selected material: AMAZONAS: Humaitá, L.O.A. Teixeira et al. 1058 (K, MG). AMAPÁ: between Rios Cujubim \& Flechal, J.M. Pires \& P.B. Cavalcante 52392 (K). PARÁ: Marajó, G.L. Sobel et al. 4631 (MG). RONDÔNIA: Alvorada d'Oeste, M.G. Silva 6305 (MG). MATO GROSSO: Jaciara, G. Hatschbach et al. 67065 (K). 
Extra-Amazonian distribution: Brazil: Tocantins, Piauí, Bahia, to Mato Grosso do Sul and Minas Gerais. Bolivia.

Note. Hyptis goyazensis seems to be only a diminutive form of $H$. crenata, and many specimens are difficult to place, therefore it is here reduced to synonymy. Hyptis goyavensis, as originally published, is a typographical error, and was later corrected by Bentham to Hyptis goyazensis in A. DC. Prodr. 12: 102 (1848). In accordance with the Vienna Code (2006) article 60.1, the latter version is the accepted form. An unusual population occurs on the Serra do Cachimbo (G.T. Prance et al. 25230 (US, NY) and may represent a new taxon.

4.8 Hyptis (Eriosphaeria) dilatata Benth., in A.P. de Candolle, Prodr. 12: 103 (1848).

Selected material: AMAZONAS: Rio Negro, $R$. Schomburgk 1029 (K). AMAPÁ: Macapá, M.H. Lima 1375 (MG). PARÁ: Portel, G.T. Prance et al. 1301 (K, S). RONDÔNIA: Cocoal, C.A. Cid et al. 4697 (MG). RORAIMA: Ilha de Maracá, J. Pruski et al. 3420 (INPA, K, MG). MATO GROSSO: Guiratinga, M.H. Lima \& J.G.S. Maia 1354 (MG).

Extra-Amazonian distribution: Brazil: ?Espirito Santo. Panamá, Venezuela, Colômbia.

4.9 Hyptis (Latiflorae) eximia Epling, Rep. Spec. Nov. Beih. 85: 223 (1936).

Selected material: MATO GROSSO: Aripuanã. M.G. Silva \& C. Rosario 4736 (F).

Although this species has not yet been recorded from our area, it is likely to be found within it. The collection was made about $150 \mathrm{~km}$ south of the boundary with Amazonas, where more fieldwork would be worth-while.

4.10 Hyptis (Xylodontes) hirsuta Kunth in Humboldt \& Bonpland, Nov. Gen. Sp. 2: 318 (1818).

Selected material: ACRE: Parime, E. Ule 8299 (MG). AMAZONAS: Manaus, R. Spruce 1270 (K). PARÁ: Óbidos, P.B. Cavalcanti 881 (MG). RONDÔNIA: Presidente Médici, N.A. Rosa et al. 4928 (K, MG). MATO GROSSO: "Xavantina-Cachimbo Expedition Base camp", 12049'S, 51046'W, R.M. Harley \& $R$. Souza 11053 (K, UB).

Extra-Amazonian distribution: Brazil: Mato Grosso do Sul, Tocantins. Venezuela, Paraguay, Bolivia.

4.11 Hyptis (Gymneia) interrupta Pohl ex Benth., Labiat. Gen. Spec.: 77 (1833).

Selected material: RONDÔNIA: Vilhena, I.S. Miranda \& P.J.D. Silva 1276 (MG). MATO GROSSO: Diamantino, G. Hatschbach et al. 62668 (K, MBM).
Extra-Amazonian distribution: Brazil: Mato Grosso do Sul, Minas Gerais, Goiás.

4.12 Hyptis (Plagiotis) laciniata Benth., Hooker's J. Bot. 2: 49 (1840).

Selected material: ACRE: Rio Branco, Canamé, J.G. Kuhlmann 819 (LAinUC ex RB).

Extra-Amazonian distribution: Guyana, Venezuela (Amazonas), Eastern Colombia. Its present distribution suggests that it may be found elsewhere, not only in Amazonian Brazil, but also possibly in Amazonian Peru.

4.13 Hyptis (Hyptis) lacustris A.St.-Hil. ex Benth., Labiat. Gen. Spec.: 107 (1833).

Selected material: ACRE: Rio Branco, J.U. Santos et al. 23 (K, MG). AMAZONAS: Rio Bauana, P.L. Krieger et al. 12796 (HUEFS, SPF). PARÁ: Serra do Cachimbo, J.M. Pires et al. 6139 (UB). RONDÔNIA: GuajaraMirim, L. Carreira et al. 384 (MG). MATO GROSSO: Aripuanã, M.G. Silva \& J. Maria 3188 (K, MG).

Extra-Amazonian distribution: Distribution discontinuous between Amazonian regions of Venezuela, Guyana, Colômbia, Peru and Bolívia, and extra-Amazonian populations in southern Brazil, from Rio de Janeiro to Rio Grande do Sul.

4.14 Hyptis (Hyptis) lanceolata Poir. in Lam., Encycl., Suppl. 3: 114 (1813).

Selected material: ACRE: Cruzeiro do Sul, T.B. Croat et al. 62655 (INPA). AMAZONAS: Manaus, M. Nee 42559 (K, NY). AMAPÁ: Porto Platon, J.M. Pires et al. 51032 (MG). PARÁ:Almeirim, J.M. Pires \& N.T. Silva 966 (MG). MARANHÃO: Turiaçu, N.A. Rosa \& H. Vilar 2809 (MG). Extra-Amazonian distribution: Caribbean especially Cuba, Guianas, Venezuela (rare), Brazil: Pernambuco south to Minas Gerais and São Paulo.

4.15 Hyptis (Hyptis) lantanifolia Poit., Ann. Mus. Hist. Nat. 7: 468 (1806).

Selected material: AMAZONAS: Manaus, Reserva Florestal Ducke, M.A.S. Costa 513 (MG). AMAPÁ: road to Amapá, Pires, J.M. \& Cavalcanti, P.B. 52017 (K, MG). PARÁ: São Geraldo do Araguaia, M.N. Bastos \& M.R. Cordeiro 1926 (MG). RORAIMA: Vila Pacaraima, S.S. Almeida \& M. Cordeiro 548 (MG). MATO GROSSO: Rondonópolis, T.M. Pedersen 12223 (C, K).

Extra-Amazonian distribution: Widely distributed from Mexico, the Caribbean and Guianas, south to Peru, Bolivia. Brazil, south to São Paulo.

4.16 Hyptis (Hyptis) lorentziana O. Hoffm., Linnaea 43: 137 (1881).

Selected material: AMAZONAS: Ilha do Careiro, G.T. Prance \& J.F. Ramos 23297 (MG). AMAPÁ: Serra do 
Navio, L.A. Pereira 543 (MG). PARÁ: Senador José Porfírio, S.S. Almeida 184 (MG). RONDÔNIA: Alta Floresta d'Oeste, L.C.B. Lobato et al. 1718 (MG). MATO GROSSO: Cáceres, G. Hatschbach et al. 62400 (K).

Extra-Amazonian distribution: Brazil: Bahia south to Mato Grosso do Sul and Rio Grande do Sul. Bolivia, Paraguay and Argentina.

4.17 Hyptis (Cyrta) microphylla Pohl ex Benth., Labiat. Gen. Spec.: 82 (1833).

Selected material: RORAIMA: Alto Alegre, M.J.G. Hopkins et al. 862 (INPA, K). MATO GROSSO: Nova Xavantina: Rio das Mortes, R.M. Harley \& R. Souza 11099 (K, UB).

Extra-Amazonian distribution: Cuba, Guyana, Venezuela, Bolívia, Paraguay, Uruguay and widespread in Brazil: from Mato Grosso do Sul, in the West, to Piauí and Bahia, in the Northeast; and from Goiás and the Distrito Federal south to Minas Gerais, Rio de Janeiro and São Paulo.

4.18 Hyptis (Cyrta) microsphaera Epling, Bull. Torrey Bot. Cl. 71: 495 (1944).

Selected material: PARÁ: Sete Varas, J.J. Strudwick et al. 4233 (K, MG).

Also known from Venezuela (Anzoategui) and Surinam.

4.19 Hyptis (Polydesmia) mutabilis (Rich.) Briq., Bull. Herb. Boissier 4: 788 (1896).

Selected material: ACRE: Porto Valter, D.C. Daly et al. 11759 (K, NY). AMAZONAS: Fonte Boa, M. Silva 1977 (MG). AMAPÁ: Rio Jarí, W.A. Egler \& H.S. Irwin 46054 (K, MG). PARÁ: Óbidos, A. Ducke 10230 (MG). MATO GROSSO: Poconé, R.M. Harley et al. 55365 (HUEFS).

Extra-Amazonian distribution: Widespread in Tropical America from the SE United States and the Caribbean southwards to Paraguay, Peru, Bolivia, southern Brazil and Argentina. Introduced into Old World.

This, as its name suggests occurs in many forms, individual plants may be densely hairy to almost completely glabrous, the spiciform inflorescence may be very compact to laxer with longer pedunculate cymules, the cymules may be few-flowered or more typically up to c. 15-flowered and the fruiting calyx may elongate greatly in fruit, or only slightly. As many of these characters occur in various combinations, it is difficult to arrive at a useful and consistent varietal classification As the species is often dispersed by human activity, many plants occurring in disturbed habitats, the confused pattern of variation may be due to the mixing of populations, formerly genetically and geographically distinct. Much material from Amazonia tends to be subglabrous with lax inflorescences.

4.20 Hyptis (Xylodontes) nigrescens Pohl ex Benth., Labiat. Gen. Spec.: 111 (1833).

Selected material: RONDÔNIA: A.S.L. Silva \& C.S. Rosário 4558 (MG). MATO GROSSO: Pontes e Lacerda, A. Souza et al. 1424 (R).

Extra-Amazonian distribution: Brazil: Goiás, Mato Grosso do Sul.

4.21 Hyptis (Eriosphaeria) obtecta Benth. in A.P. de Candolle, Prodr. 12: 99 (1848).

Selected material: PARÁ: São Geraldo do Araguaia, $I$. Aragão 164 (MG). MATO GROSSO: Nova Xavantina, D.R. Hunt 5545 (K, UB).

Extra-Amazonian distribution: Brazil: Tocantins, Goiás, Bahia. A species of damp, open savannas.

4.22 Hyptis (Hyptis) parkeri Benth., Labiat. Gen. Spec.: 108 (1833).

Selected material: AMAZONAS: Manaus, S. Keel \& J. Guedes 340 (MG). AMAPÁ: Macapá, B. Rabelo \& Jonas 1176 (MG). PARÁ: Altamira, A.T.G. Dias et al. 812 (MG). RONDÔNIA: Porto Velho, L.C.B. Lobato et al. 1887 (MG). RORAIMA: Boa Vista, N.A. Rosa \& M.R. Cordeiro 1480 (MG). MARANHÃO: J. Jangoux \& R.P. Bahia 388 (MG, NY). MATO GROSSO: Nova Xavantina: Rio Suiá Missu, R.M. Harley \& R. Souza 11138 (K, UB).

Extra-Amazonian distribution: Guyana, Venezuela, Colombia, Bolivia. Brazil: Rio de Janeiro (?).

4.23 Hyptis (Mesosphaeria) pectinata (L.) Poit., Ann. Mus. Hist. Nat. 7: 474 (1806).

Selected material: PARÁ: Marabá, R. Secco et al. 207 (K, MG).

Extra-Amazonian distribution: Throughout much of tropical America from southern United States (Florida) and the Caribbean to the Guianas, $\mathrm{S}$ to Peru, Bolivia and S Brazil, where often a common weed. Introduced in tropical Africa, Asia and the Pacific. Apparently almost absent from Amazonian Brazil and Mato Grosso and from more humid regions.

4.24 Hyptis (Apodotes) pulegioides Pohl ex Benth., Labiat. Gen. Spec.: 128 (1833).

Selected material: ACRE: Rio Branco, E. Ule 8296 (MG). MATO GROSSO: Cuiabá, Malme 1738 (S).

Extra-Amazonian distribution: Cuba, Guyana, Venezuela, Colombia, Bolivia, scattered through Brazil, from South of the Amazon from Tocantins 
and Goiás, Pernambuco to Minas Gerais. Undoubtedly under-recorded and often mistaken for Hyptis brevipes. Usually found in damp savanna.

4.25 Hyptis (Cyrta) recurvata Poit., Ann. Mus. Hist. Nat. 7: 467 (1806).

Selected material: ACRE: Rio Branco, H.G.V. Silva \& L. Lima 95 (K). AMAZONAS: Careiro, D. Coelho \& Umbelino s.n. (MG). AMAPÁ: Água Azul, J.M. Pires \& P.B. Cavalcanti 52270 (K). PARÁ: Oriximana, S.S. Almeida 266 (MG). RORAIMA: Ilha de Maracá, $W$. Milliken 812 (E, K). MARANHÃO: Loreto, G. Eiten \& L.T. 5400 (K). MATO GROSSO: Alto Araguaia, G. Hatschbach 34658 (C, K).

Extra-Amazonian distribution: Widespread from Southern Mexico through Central America to Trinidad and northern South America, Brazil: throughout. Uruguay, northern Argentina and Bolivia. A semi-ruderal species of damp places.

4.26 Hyptis (Mesosphaeria) spicigera Lam., Encycl. 3: 185 (1789).

Selected material: ACRE: Rio Branco, E. Ule 7894 (MG, K). AMAZONAS: Manaus, M. Nee 42736 (INPA, K). AMAPÁ: Rio Apurema, R.L. Froés \& G.A. Black 27601 (UB). PARÁ: Carajás, J.A.A. Bastos 189 (MG). RORAIMA: Ilha de Maracá, W. Milliken \& C.D.A. Mota 603 (E, K). MARANHÃO: Açailândia, F. Cardoso et al. 295 (MG).

Extra-Amazonian distribution: Widespread as a weed of cultivation throughout tropical America, except in the extreme south, and also introduced into the Old World.

4.27 Hyptis (Mesosphaeria) suaveolens (L.) Poit., Ann. Mus. Hist. Nat. 7: 472 (1806).

Selected material: ACRE: J.G. Kuhlmann 798 (RB). AMAPÁ: Porto Platon, M.G. Silva 2785 (INPA, K). AMAZONAS: Manaus-Itacoatiara, M. Dantas 35 (INPA). PARÁ: Almeirim, J.M. Pires \& N. Silva 1269 (K). RONDÔNIA: Ariquemes, L.O.A. Teixeira et al. 371 (MG, INPA). RORAIMA: Mucajaí, E.L. Setta Silva 725 (K). MARANHÃO: São Luis, G.T. Prance \& R. Henriques 29894 (NY). MATO GROSSO: Cervo, W. Hoehne \& A. Gehrt s.n. (SP, HUEFS).
Extra-Amazonian distribution: Throughout most of the Tropics as a weed of cultivation and waste ground. Common throughout Brazil, except in the extreme South.

4.28 Hyptis sp. nov, ined. (Sect. Gymneia). Selected material: PARÁ: *Itaituba, I.L. Amaral et al. 963 (K, MG, NY, RB).

Extra-Amazonian distribution: None, endemic. Note: This species, shortly to be published, was collected on the Serra do Cachimbo, near the road between Santarem and Cuiabá. It represents the northernmost collection of any species of this section, species of which typically occur in savanna habitats, often cerrado, although with one species a semi-ruderal in the caatinga of NE Brazil. The new species is related to $H$. interrupta, which is recorded from Rondônia and further south, and is characterized by its very slender spikes of remote verticillasters, of congested flowers, borne on an erect axis, with the leaves near the base of the stem. The fruiting calyx tube is strongly deflexed, just below the throat. Further collections are needed.

*At the time of the collection was made, the locality were it was collected, was situated in the Municipio of Itaituba, mentioned on the label. However this has since been divided. The locality where this collection was made is now named Novo Progresso.

5. Marsypianthes Mart. ex Benth.

5.1 Marsypianthes chamaedrys (Vahl) Kuntze, Revis. Gen. Pl. 2: 524 (1891).

Selected material: ACRE: Rio Branco, J.V. Santos et al. 96 (K, INPA). AMAZONAS: Reserva Florestal Ducke, M.A.S. Costa et al. 123 (K, INPA). AMAPÁ: sin. loc., J. Huber 1187 (MG). PARÁ: São Domingos do Capim, P.B. Cavalcante 2999 (MG). RONDÔNIA: Porto Velho, A.P. Duarte et al. 7206 (K). RORAIMA: Boa Vista, J.A. Silva et al. 507 (INPA). MARANHÃO: Vitória do Mearim, L.S. Carneiro 15A (MG). MATO GROSSO: Nova Xavantina, R.M. Harley et al. 10784 (K, UB).

Extra-Amazonian distribution: Widespread throughout Tropical America, southern United States and Caribbean, south through Meso- and S America to Peru and Argentina.

\section{Ocimum L.}

1. Bracts deciduous, with a bowl-like gland forming under cymes .................................................... 2

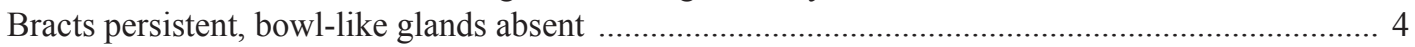

2. Fruiting calyx bent downwards at throat, forming a right-angle with the tube; upper lip much expanded, reniform O. transamazonicum

Fruiting calyx straight; upper lip not so much expanded, obovate 3 
3. Leaves mostly in a basal rosette O. nudicaule

Leaves regularly arranged up stem O. carnosum

4. Throat of fruiting calyx closed, median lobes of lower lip pressed against upper lip; leaves mostly $>40 \mathrm{~mm}$ long O. gratissimum*

Throat of fruiting calyx open, upper and lower lips held apart 5

5. Calyx glabrous at throat, posterior stamens without filament appendages near base, but sometimes barbate; nutlets not or only weakly mucilaginous when wet ..... Calyx with dense ring of hairs at throat, posterior stamens with flattened filament appendage, glabrous or hairy, at base; nutlets copiously mucilaginous when wet ............................. 9

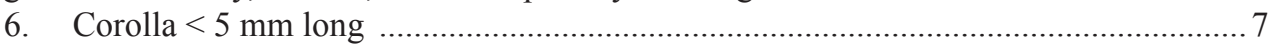

Corolla $>5 \mathrm{~mm}$ long 8

7. Fruiting calyx $6.5-10 \mathrm{~mm}$ long, with broad decurrent margin on upper lip forming a conspicuous wing; posterior stamens glabrous 1. O. campechianum Fruiting calyx 4-6 mm long, with decurrent margin on upper lip inconspicuous; posterior stamens with small tuft of hairs at base of filament ...... O. tenuiflorum* 8. Leaves sessile or petiole rarely $1 \mathrm{~mm}$ long, lamina \pm rotund (species of $\mathrm{E}$ Paraguay) O. hassleri Leaves petiolate, usually $>3 \mathrm{~mm}$ long, rarely less, lamina ovate ..... O. ovatum 9. Cultivated herb or subshrub with fastigiate branches; leaves $<20 \times 10 \mathrm{~mm}$ O. minimum*

Cultivated herbs; branches not fastigiate; leaves not as above, larger ... 10 10. Stem glabrous, or minutely puberulent on 2 opposing faces O. basilicum*

Stem pubescent with retrorse or patent hairs distributed equally round stem of simple, mostly gland-tipped hairs 11

11. Fruiting calyx $5-6 \mathrm{~mm}$ long, anthers $>0.6 \mathrm{~mm}$ diam. (dried material) O. africanum* Fruiting calyx $4-5 \mathrm{~mm}$ long, anthers $\pm 0.5 \mathrm{~mm}$ diam. O. americanum*

Note: *Species introduced from the Old World and found in cultivation.

6.1 Ocimum campechianum Mill., Gard. Dict. ed. 8, 5 (1768). Ocimum micranthum Willd., Enum. Pl. 2: 630 (1809).

Selected material: ACRE: Brasileia, B.W. Nelson et al. 843 (INPA). AMAZONAS: Rio Abacaxis, Axinim, S.R. Hill 12995 (UB). PARÁ: Oriximiná, Rio Trombetas, C.A. Cid \& J. Ramos 1047 (INPA, K). MARANHÃO: Loreto, G. Eiten \& L.T. Eiten 10424 (UB). MATO GROSSO: Nova Xavantina, D. Philcox \& A. Fereira 3972 (K, UB).

Extra-Amazonian distribution: Widespread throughout Tropical America, and sometimes in cultivation.

\begin{abstract}
Note: Several other taxa, introduced from the Old World, are cultivated in Brazil. Ocimum africanum Lour. (syn. $O$. x citriodorum Vis.) is a common species, originally derived from a cross between $O$. basilicum $\mathrm{L}$. and $O$. americanum $\mathrm{L}$., both of which are cultivated in Brazil and the latter naturalized especially in the Northeast. Other species sometimes encountered in cultivation are $O$. minimum $\mathrm{L}$., a species unknown in the wild, $O$. tenuiflorum L. (syn. O. sanctum L.) and the native species, O. carnosum (Spreng.) Link \& Otto ex Benth. (syn. O. selloi Benth.), which is a species of southern Brazil. The key includes all species, wild and cultivated, known to occur in Brazil.
\end{abstract}

\section{Peltodon Pohl}

1. Subshrub with several stems to $20 \mathrm{~cm}$ tall from woody swollen xylopodium, leaves pale green, subglabrous, subsessile; capitula with involucral bracts yellowish, peduncles $5-15 \mathrm{~cm}$ long 1. P. pusillus

Subshrub or herb with stem to $40 \mathrm{~cm}$ or more, leaves and stems hairy, leaves rather dark green, slightly discolorous; capitula with involucre green, peduncles $3-10 \mathrm{~cm}$. long 2. P. tomentosus 
7.1 Peltodon pusillus Pohl, Pl. Bras. Icon. Descr. 1: 67 (1827).

Selected material: RONDÔNIA: Vilhena, M.G. Vieira et al. 792 (INPA, K). MATO GROSSO: Chapada dos Guimarães, G.T. Prance et al. 18955 (INPA, K).

Extra-Amazonian distribution: Brazil: Goiás and Tocantins. Bolivia.

7.2 Peltodon tomentosus Pohl, Pl. Bras. Icon. Descr. 1: 69 (1827).

Selected material: RONDÔNIA: Vilhena, M.G. Silva \& C. Rosario 4642 (MG, INPA). MATO GROSSO: Barra do Garças, Ratter, J.A. et al. 4146 (E, K).

Extra-Amazonian distribution: Brazil: Bahia, Minas Gerais, Mato Grosso, Mato Grosso do Sul, Paraná, São Paulo. Bolivia, Paraguay. A semiruderal species in most areas.

\section{Scutellaria L.}

8.1 Scutellaria agrestis A. St-Hil. ex Benth., Labiat. Gen. Spec.: 427 (1834).

Selected material: ACRE: Xapuri, K.A. Kainer 123 (NY). PARÁ: Benvides, Z. Castilhos $25^{a}(\mathrm{~K}, \mathrm{NY})$. (Cultivated).

Extra-Amazonian distribution: NE Brazil, Minas Gerais. Trinidad, Peru, Ecuador.

8.2 Scutellaria incarnata Vent., Choix Pl.: 39 (1803). Scutellaria ventenatii Hook., Bot. Mag. 72: t. 4271 (1846).

Selected material: ACRE: Xapuri, C. Figueiredo 284 $(\mathrm{K}, \mathrm{NY})$.

Extra-Amazonian distribution: Venezuela, Colombia and Ecuador. In Brazil, only known from Acre State.

8.3 Scutellaria leucantha Loes., Verhandl. Bot. Ver. Prov. Brandenb. 47: 187 (1905).

Selected material: AMAZONAS: E. Ule 5930(TYPE)(MG).

Extra-Amazonian distribution: None.

8.4 Scutellaria aurata Lemaire, Ill. Hort. 10, t. 368 (1863).

Syn.: Scutellaria speciosa Epling.

Note: This species was described from cultivated material and said to originate from the Brazilian Amazon. It is well illustrated in Lemaire's original account, and there is little doubt (Harley \& Paton 1999) that it is conspecific with Scutellaria speciosa. All other records are from the eastern side of the Andes, in Peru and Ecuador, but no extant material is known from Brazil. It seems possible that the provenance of Lemaire's plant, as stated by him, was erroneous.
Naturalized species

A small number of species, included in the generic key, are introduced from the Old World, and may be established in the area as weeds of cultivation or on waste ground: Leonotis nepetifolia (L.) R.Br. is a robust herb with conspicuous orange, two-lipped flowers in dense verticillasters, Leonurus japonica Houtt., formerly identified erroneously as Leonurus sibirica L., is another robust herb with pink, twolipped flowers and deeply palmately divided leaves. Leucas martinicensis (Jacq.) R.Br., also an erect herb, has unlobed leaves, with dense globose verticillasters from leaf-axils, and rather small, white, two-lipped flowers. This last has not yet been reported from the flora area, but may well occur.

\section{Acknowledgements}

Much of this paper stems from visits to the herbaria of the Museu Goeldi (MG) in Belém and in the Instituto Nacional de Pesquisas Amazonicas (INPA) in Manaus, and I should like to thank the Curators and staff for permission to examine their collections and for the great kindness shown to me. I should also like in the same way, to thank those especially of the University of Brasília (UB), the Botanical Gardens of Rio de Janeiro (RB), of New York (NY) and of Kew (K). and members of staff at the herbarium of the Universidade de Feira da Santana (HUEFS), Bahia, for similar help. I should also like to thank Alan Paton, RBG Kew, who kindly advised me on Scutellaria and Ocimum, and, from the same institution, Justin Moat who kindly prepared the excellent map. Finally I thank Ana Maria Giulietti for encouragement and advice in the preparation of this paper, and also the two unknown reviewers, whose comments helped greatly to improve its content.

\section{References}

Epling, C. 1935-7. Synopsis of the South American Labiatae. Repertorium specierum novarum regni vegetabilis. Beihefte 85: 1-341.

Epling, C. 1942. The American species of Scutellaria. University of California Publications in Botany 20: 1-137.

Epling, C. 1949. Revisión del género Hyptis (Labiatae). Revista del Museu de La Plata, Sección Botánica 7: 153-497.

Harley, R.M. 1976. A Review of Eriope and Eriopidion (Labiatae). Hooker's Iconographia Plantarum. Longman, London 38, 3: 1-107.

Harley, R.M.; Atkins, S.; Budantsev, A.; Cantino, P.H.; Conn, B.; Grayer, R.; Harley, M.M.; Kok, R.; 
Krestovskaja, T.; Morales, A.; Paton, A.J.; Ryding, O. \& Upson, T. 2004. Labiatae. In: Kadereit, J.W. (ed.). The families and genera of vascular plants (Kubitzki, K.: ed.). Vol. 7. Pp. 167-275.

Harley, R.M.; França, F.; Santos, E.P. \& Santos J.S. 2010. Lamiaceae. In: Catálogo de plantas e fungos do Brasil. Vol. 2. Jardim Botânico do Rio de Janeiro, Rio de Janeiro. Pp. 1130-1146.

Harley, R.M. \& Pastore, J.F.B. In press. A generic revision and new combinations in the Hyptidineae (Lamiaceae), based on molecular and morphological evidence. Phytotaxa.

Harley, R.M. \& Paton, A. 1999. Notes on new world Scutellaria. Kew Bulletin 54: 221-225.
Pastore, J.F.B.; Harley, R.M.; Forrest, F.; Paton, A.J. \& van den Berg, C. 2011. Phylogeny of the subtribe Hyptidinae (Lamiaceae tribe Ocimeae) as inferred from nuclear and plastid DNA. Taxon 60: 1317-1329.

Paton, A.; Harley, R.M. \& Harley, M.M. 1999. Ocimum: an overview of classification and relationships. In: Holm, Y. \& Hiltunen, R. (eds.). Ocimum. Medicinal and aromatic plants - industrial profiles. Hardman, Harwood Academic, Amsterdam. 167p.

Yuan, Y.W.; Mabberley, D.J.; Stean, D.A. \& Olmstead, R.G. 2010. Further disintegration and redefinition of Clerodendrum (Lamiaceae): implications for the understanding of the evolution of an intriguing breeding strategy. Taxon 59: 125-133. 